\title{
KAJIAN PERSEBARAN KOMODITAS TEH: PENGEMBANGAN KAWASAN PERKEBUNAN TEH DI PROVINSI JAWA BARAT TAHUN 2015
}

\author{
Release Study Of Tea Commodities: Development Of Tea Plantation Area In West \\ Java Province In 2015
}

\section{Muhammad Basorudin*, Aniisa Rizqi, Sri Murdaningrum, Windi Maharani}

\author{
Badan Pusat Statistik \\ J1. Dr. Sutomo, No. 6-8, Jakarta \\ *Kontak penulis: $\underline{\text { m.basorudin@gmail.com }}$
}

\begin{abstract}
Tea is one of the main commodities that is a mainstay of Indonesian exports and has been exported to 78 countries on five continents. However, the development of the volume of Indonesian tea exports tends to decline from 2011 to 2015. This is due to several factors such as decreased production, downstream program that is not running optimally, limited land, and others. Therefore, this study aims to find out which districts are potential areas and non-potential areas in West Java Province as the largest tea-producing region in Indonesia. Then, to find out the growth rate of tea production in each district in West Java Province and how the area is spread based on its potential. The method used is Location Quotient, Shift Share, and Quadrant Method. Based on the research, it was found that the area that has potential and became the basis so that its construction can contribute significantly to tea plantations in West Java Province are Bandung, Cianjur, Purwakarta, Bandung Barat, Garut, Tasikmalaya, and Sukabumi. Then, the calculation results with this quadrant indicate that the mainstay tea plantation area is in the Sukabumi, Cianjur, Bandung, Garut, and West Bandung regions.
\end{abstract}

Keywords: Tea; Location Quotient; Shift Share; Quadrant Method.

\begin{abstract}
Abstrak
Teh merupakan salah komoditas utama yang menjadi andalan ekspor Indonesia dan telah diekspor ke 78 negara di lima benua. Namun, perkembangan volume ekspor teh Indonesia cenderung mengalami penurunan dari tahun 2011 sampai tahun 2015. Hal ini dikarenakan beberapa faktor seperti penurunan produksi, program hilirisasi yang tidak berjalan maksimal, lahan yang terbatas, dan sebagainya. Oleh karena itu, penelitian ini bertujuan untuk mengetahui kabupaten yang menjadi kawasan potensial dan kawasan tidak potensial di Provinsi Jawa Barat sebagai daerah penghasil teh terbesar di Indonesia. Kemudian, untuk mengetahui laju pertumbuhan produksi teh tiap kabupaten di Provinsi Jawa Barat dan bagaimana persebaran kawasan berdasarkan potensinya. Metode yang digunakan ialah Location Quotien (LQ), Shift Share (SS), dan Metode Kuadran. Berdasarkan penelitian, didapatkan wilayah yang memiliki potensi dan menjadi basis sehingga pengambangan dapat memberikan sumbangsih secara signifikan pada perkebunan teh di Provinsi Jawa Barat adalah Bandung, Cianjur, Purwakarta, Bandung Barat, Garut, Tasikmalaya, dan Sukabumi. Kemudian, hasil perhitungan dengan kuadran ini menunjukkan
\end{abstract}


bahwa kawasan perkebunan teh yang andalan terdapat pada wilayah Sukabumi, Cianjur, Bandung, Garut, dan Bandung Barat.

Kata Kunci: Teh; Location Quotien; Shift Share; Metode Kuadran.

Sitasi: Basorudin dkk, 2019. Kajian Persebaran Komoditas Teh: Pengembangan Kawasan Perkebunan Teh di Provinsi Jawa Barat Tahun 2015 , Jsep 14(3): 205 - 214.

\section{Pendahuluan}

Sektor pertanian merupakan sektor yang mempunyai peran cukup penting dalam perekonomian Indonesia. Hal ini dapat dibuktikan bahwa sektor pertanian memberikan kontribusi sebesar 13,52\% dalam PDB Indonesia pada tahun 2015 dan menjadi kontributor kedua terbesar setelah sektor industri pengolahan. Salah satu subsektornya yang mempunyai kontribusi terbesar dalam pembentukan PDB adalah subsektor perkebunan berkontribusi sekitar 3,57\% pada tahun yang sama.

Teh merupakan salah satu komoditas ekspor Indonesia yang cukup penting sebagai penghasil devisa setelah minyak dan gas. Teh sebenarnya berkontribusi dalam ekspor dan penyerapan tenaga kerja. Jumlah tenaga kerja perkebunan teh tertinggi dibandingkan komoditas agrobisnis lain, yaitu sekitar dua juta orang di Indonesia dengan menyerap rata-rata 3-4 tenaga kerja per hektar. Meski demikian, teh masih menjadi komoditas unggulan kedua. Selama ini komoditas perkebunan Indonesia yang sudah dianggap sebagai unggulan yaitu kopi, kakao, kelapa sawit, dan karet, menghasilkan nilai ekspor yang tinggi dibandingkan dengan produk perkebunan lain sehingga terlihat lebih menonjol (Radius, 2005).

Produksi teh Indonesia sebagian besar di ekspor dan hanya sebagian kecil yang dipasarkan di dalam negeri. Pada tahun 2015, sekitar 78 negara yang menjadi pangsa pasar ekspor teh Indonesia dan telah menjangkau kelima benua yakni Asia, Afrika, Australia, Amerika, dan Eropa. Namun, perkembangan volume ekspor teh Indonesia cenderung mengalami penurunan dari tahun 2011 sampai tahun 2015 menjadi 61,92 ribu ton dengan nilai sebesar US\$126,05 juta.

Di sisi lain, Indonesia juga mengimpor teh dari Vietnam, Kenya, India, Iran, dan Argentina. Bahkan perkembangan volume impor mengalami kenaikan dari tahun 2014 sampai tahun 2015 menjadi 15,16 ribu ton dengan nilai sebesar US\$25,75 juta. Volume impor tergolong cukup tinggi, yaitu sekitar 25\% dari total ekspor. Hal ini tentunya sangat mengkhawatirkan bagi perkembangan teh di Indonesia karena volume ekspor cenderung mengalami penurunan namun, volume impor mengalami peningkatan.

Provinsi Jawa Barat merupakan kontributor terbesar dalam produksi teh Indonesia denngan total produksi sekitar $68 \%$ dari produksi teh Nasional pada tahun 2015. Namun, hampir semua kabupaten di Provinsi Jawa Barat mengalami penurunan produksi dari tahun 2013 sampai tahun 2015 yang berdampak pada penurunan total produksi teh Provinsi Jawa Barat menjadi 90.324 ton. 


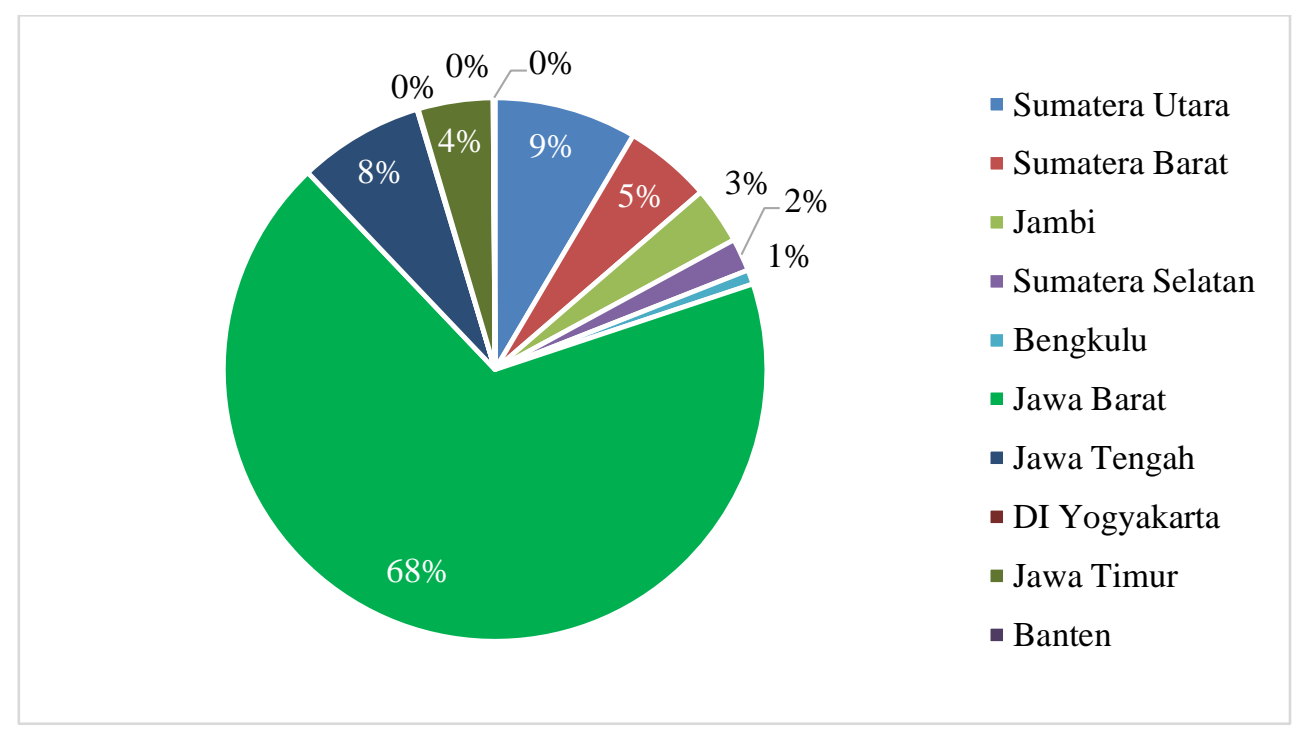

\section{Grafik 1. Produksi Teh Indonesia Tahun 2015}

Produksi teh di Provinsi Jawa Barat mengalami penurunan dari tahun 2013 sebesar 113.902 ton menjadi 90.324 ton pada tahun 2015. Penurunan tersebut berdampak pada penurunan volume ekspor dan peningkatan volume impor Indonesia pada tahun 2015.

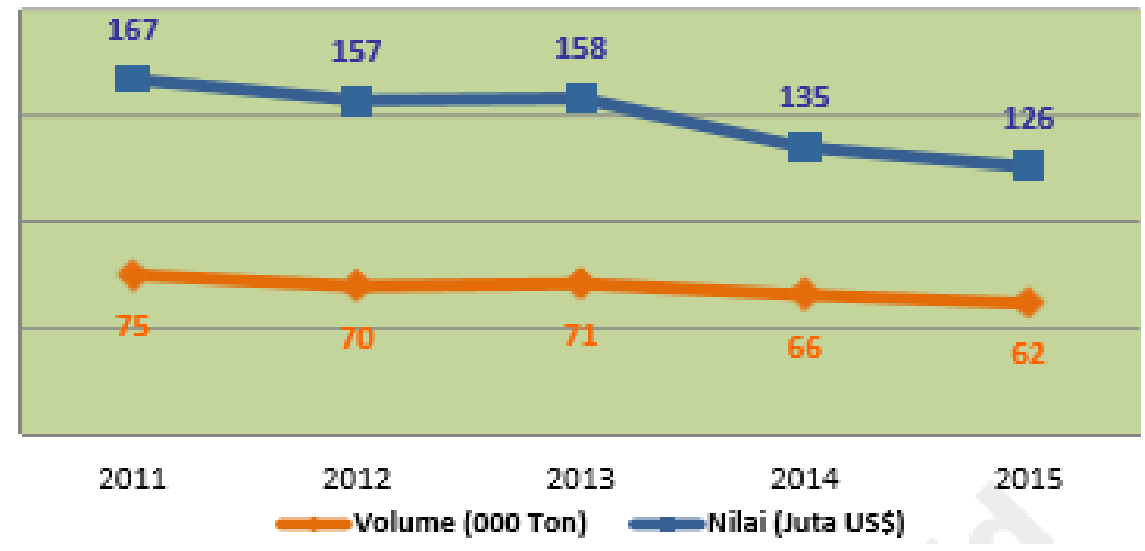

Grafik 2. Perkembangan Volume dan Nilai Ekspor Teh Indonesia, 2011-2015

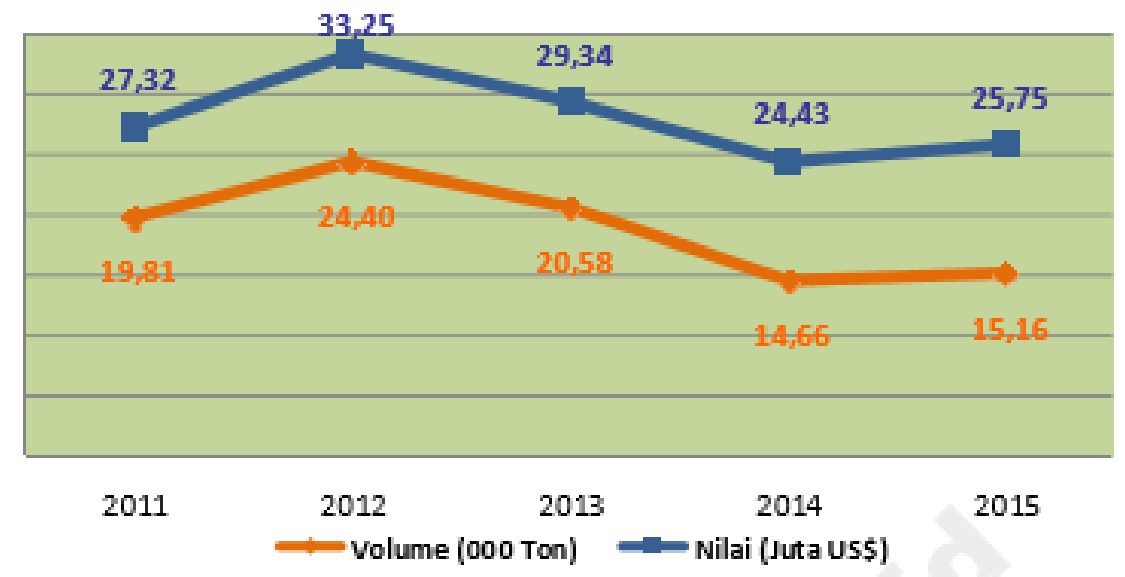

Grafik 3. Perkembangan Volume dan Nilai Impor Teh Indonesia, 2011-2015 
Penurunan volume teh Indonesia pada dari tahun 2011 hingga tahun 2014 dikarenakan program hilirisasi produk teh yang tidak berjalan maksimal. Sejauh ini, ekspor teh masih tergantung pada produk primer. Selain itu, penurunan ekspor teh disebabkan oleh kenaikan biaya produksi, kualitas teh yang rendah, serta target standardisasi yang belum terpenuhi baik di tingkat nasional dan internasional (Edward, 2016). Kemudian, peralatan produksi yang belum modern, sumber daya manusia dan harga di tingkat petani yang rendah., serta lahan teh yang semakin berkurang.

Berdasarkan uraian di atas, akan dilakukan penelitian untuk mengetahui kawasan perkebunan yang potensial dan persebaran kawasan perkebunan teh berdasarkan potensinya dari tiap kabupaten di Provinsi Jawa Barat agar dapat ditentukan metode pengembangan yang sesuai untuk tiap kawasan perkebunan di Provinsi Jawa Barat.

Sebagai salah satu penghasil teh terbesar di Indonesia, produksi teh di Provinsi Jawa Barat mengalami penurunan dari tahun 2013 sampai tahun 2015 yang berdampak pada penurunan volume ekspor dan peningkatan volume impor teh Indonesia pada tahun 2015. Jika hal tersebut berlangsung terus-menerus maka dikhawatirkan akan terjadi defisit pada neraca perdagangan teh Indonesia. Oleh karena itu, diperlukan suatu penelitian untuk mengetahui kawasan perkebunan yang potensial dan kawasan yang tidak potensial sehingga dapat mengetahui metode pengembangan yang sesuai untuk meningkatkan produktivitas teh di Provinsi Jawa Barat.

Berdasarkan penjelasan tersebut tujuan dari penelitian ini adalah sebagai berikut:

1. Untuk mengetahui kabupaten yang menjadi kawasan potensial dan kawasan tidak potensial di Provinsi Jawa Barat.

2. Untuk mengetahui laju pertumbuhan produksi teh tiap kabupaten di Provinsi Jawa Barat.

3. Untuk mengetahui persebaran kawasan berdasarkan potensi komoditas teh di Provinsi Jawa Barat.

Penelitian tentang Pengembangan Kawasan Perkebunan Teh di Kabupaten Bandung oleh Darmawansyah dan Sardjito (2012), menganalisis basis potensi perkebunan teh di Kabupaten Bandung guna meminimalisasi efek dari penurunan produktivitas teh dan memberikan arah kebijakan pengembangan perkebunan teh untuk meningkatkan pendapatan dan kesejahteraan rakyat. Teknik analisis yang digunakan dengan analisis identifikasi potensi komoditas teh melalui teknik analisis LQ, Shift Share, dan Kuadran. Hasil perhitungan komparasi menunjukkan bahwa kawasan perkebunan teh yang potensial adalah di wilayah selatan Kabupaten Bandung, khususnya di Kecamatan Ciwidey, Rancabali, Pangalengan, Kertasari, dan Pasirjambu.

Salah satu penelitian yang menganalisis komoditas perkebunan unggulan sebagai potensi suatu kabupaten untuk masing-masing kecamatannya adalah penelitian oleh Setianto dan Susilowati (2014). Dalam penelitian tersebut dikatakan bahwa penentuan komoditas perkebunan unggulan pada masing-masing kecamatan digunakan metode Location Quotient (LQ). Untuk mengidentifikasi pertumbuhan komoditi dalam suatu kecamatan menggunakan analisis pertumbuhan wilayah (Shift 
dan Share). Selanjutnya dilakukan Analisis Gabungan dari hasil-hasil analisis LQ dan analisis pertumbuhan wilayah dengan metode Delphi untuk mengetahui keunggulan dari komoditas yang sedang dianalisis. Komoditas yang sangat unggul akan memiliki nilai gabungan yang paling tinggi.

Hasil analisis pada penelitian ini menunjukkan bahwa salah satu komoditas basis atau unggulan yang disoroti dalam penelitian ini adalah komoditas perkebunan teh. Nilai LQ dari tahun 2011-2012, hasil rata-rata yang didapatkan memiliki nilai LQ luas panen paling besar adalah teh yang berarti komoditas tersebut merupakan komoditas basis jika dibandingkan dengan kabupaten lain di Jawa Tengah. Kecamatan dengan komoditas teh sebagai basis adalah pada kecamatan Batang, Pekalongan, dan Pemalang.

\section{Metode Penelitian}

Dalam penelitian ini, data yang digunakan untuk menghitung LQ dan SS adalah data cross section dari kabupaten/kota di Provinsi Jawa Barat pada tahun 2015. Sumber data diperoleh dari publikasi statistik yang dihasilkan oleh Badan Pusat Statistik (BPS). Metode analisis yang digunakan pada penelitian ini yaitu location quotien, shift share, dan metode kuadran.

\section{Location Quotien (LQ)}

\section{Rumus perhitungan LQ yang digunakan adalah sebagai berikut,}

Teknik LQ merupakan salah satu cara matematis untuk menentukan potensi komoditas pada suatu wilayah tertentu. LQ juga digunakan untuk mengetahui suatu komoditas sebagai komoditas basis atau non basis. Adapun rumus penghitungannya adalah sebagai berikut:

$$
L Q=\frac{X r / R V r}{X n / R V n}
$$

dimana:

$\mathrm{Xr}$ : nilai produksi komoditas teh pada kabupaten;

$\mathrm{Xn}$ : nilai produksi komoditas teh pada provinsi;

$\mathrm{RVr}$ : total produksi komoditas sektor perkebunan pada kabupaten;

$\mathrm{RVn}$ : total produksi komoditas sektor perkebunan pada provinsi;

Penghitungan LQ dilakukan untuk mengetahui peranan komoditas teh sebagai komoditas basis atau komoditas non basis. Apabila LQ>1 maka komoditas dikatakan "basis" yang berarti memiliki keunggulan dan dapat diekspor ke wilayah lain. Apabila $\mathrm{LQ}=1$ maka komoditas dikatakan "non basis" yang berarti tidak memiliki keunggulan namun cukup untuk memenuhi kebutuhan wilayahnya sendiri, sedangkan LQ $<1$ menunjukkan bahwa komoditas juga dikatakan "non basis" namun juga tidak dapat memenuhi kebutuhan wilayahnya sendiri.

\section{Shift Share}

Teknik analisis Shift Share dihitung berdasarkan tiga komponen pendukung, yaitu perhitungan National Share (NS), Proposional Share (PS), Differential Shift (DS), dan Total Share (TS). Penghitungan NS digunakan untuk mengukur perbandingan 
laju pertumbuhan produksi komoditas kabupaten provinsi, dengan rumus sebagai berikut:

dimana:

$$
N S=V A r . i(t-n) \times\left\{\frac{V A n(t)}{V A n(t-n)}\right\}
$$

VAr.i(t-n) : Nilai tambah komoditas teh kabupaten i tahun awal;

VAn(t) : Nilai tambah komoditas teh kabupaten i tahun tertentu;

VAn(t-n) : Nilai tambah komoditas teh provinsi Jawa Barat tahun awal.

Penghitungan PS digunakan untuk mengukur pertumbuhan produksi komoditas kabupaten secara provinsi dimana akan ada dua kriteria yang dihasilkan. Jika PS bernilai positif (+) maka pertumbuhan komoditas secara kabupaten tergolong cepat, sedangkan jika PS bernilai negatif (-) maka pertumbuhan komoditas secara kabupaten tergolong lambat. Adapun rumus penghitungannya adalah sebagai berikut:

dimana:

$$
P S=V A r \cdot i(t-n) \times\left\{\frac{V A n(t)}{V A n \cdot t(t-n)}-\frac{V A n(t)}{V A n(t-n)}\right\}
$$

VAr.i(t-n) : Nilai tambah komoditas i kecamatan tahun awal;

VAn.i(t) : Nilai tambah komoditas i kabupaten tahun tertentu;

VAn.i(t-n) : Nilai tambah komoditas i kabupaten tahun awal;

VAn(t) : Nilai tambah komoditas kabupaten tahun tertentu;

VAn(t-n) : Nilai tambah komoditas kabupaten tahun awal.

Perhitungan DS digunakan untuk mengukur keuntungan komoditas dari segi lokasi, dengan rumus sebagai berikut:

dimana:

$$
D S=V A r \cdot i(t) \times\left\{\frac{V A n \cdot i(t)}{V A n \cdot t(t-n)} \times V A r \cdot i(t-n)\right\}
$$

VAr.i(t) : Nilai tambah komoditas teh kabupaten tahun tertentu;

VAn.i(t) : Nilai tambah komoditas teh provinsi tahun tertentu;

VAn.i(t-n) : Nilai tambah komoditas teh provinsi tahun awal;

VAr.i(t-n) : Nilai tambah komoditas teh kabupaten tahun awal.

\section{Metode Kuadran}

Analisis kuadran dapat digunakan untuk menenentukan sektor unggulan dengan menggabungkan hasil dari metode analisis LQ dan Shift Share. Nilai Shift Share yang digunakan untuk analisis kuadran adalah Total Share (TS), yaitu jumlah dari nilai PS dan DS. Tujuan dari analisis kuadran yaitu untuk melihat deskripsi kegiatan ekonomi yang potensial berdasarkan kriteria kontribusi dan kriteria pertumbuhan.

Analisis kuadran menghasilkan empat kriteria. Jika nilai LQ $\geq 1$ dan TS bernilai (+) maka komoditas termasuk dalam kuadran "andalan". Jika nilai LQ $\geq 1$ dan TS bernilai (-) maka komoditas termasuk dalam kuadran "unggulan". Jika nilai LQ < 1 dan TS bernilai (+) maka komoditas termasuk dalam kuadran "prospektif". Jika nilai LQ $<1$ dan TS bernilai (-) maka komoditas termasuk dalam kuadran "tertinggal". 


\section{Hasil dan Pembahasan}

Berikut ini merupakan hasil penghitungan LQ dan Shift Share yang telah dilakukan guna mengidentifikasi kawasan perkebunan potensial dan laju pertumbuhan teh tiap kabupaten di Provinsi Jawa Barat pada tahun 2015.

Tabel 1. Hasil Penghitungan LQ dan Shift Share di Provinsi Jawa Barat, 2015

\begin{tabular}{|l|c|c|c|c|c|}
\hline \multicolumn{1}{|c|}{ Kabupaten/Kota } & LQ & NS & PS & DS & TS \\
\hline 1. Bogor & 0,51 & $-3,52$ & 83,34 & $-83644,44$ & $-83561,10$ \\
\hline 2. Sukabumi & 1,14 & $-117,05$ & $-10715,80$ & 4322309,03 & 4311593,23 \\
\hline 3. Cianjur & 2,72 & 18,41 & $-4013,91$ & 3847673,27 & 3843659,36 \\
\hline 4. Bandung & 2,92 & 511,68 & $-7179,72$ & 62452923,91 & 62445744,19 \\
\hline 5. Garut & 1,28 & $-1,48$ & $-629,77$ & 1691753,79 & 1691124,02 \\
\hline 6. Tasikmalaya & 1,19 & $-555,61$ & 7051,94 & $-32481,63$ & $-25429,69$ \\
\hline 7. Ciamis & 0,01 & $-2,40$ & $-611,92$ & 11057,78 & 10445,87 \\
\hline 8. Kuningan & 0,00 & 0,00 & 0,00 & 0,00 & 0,00 \\
\hline 9. Cirebon & 0,00 & 0,00 & 0,00 & 0,00 & 0,00 \\
\hline 10. Majalengka & 0,07 & 12,97 & 528,80 & $-40632,27$ & $-40103,48$ \\
\hline 11. Sumedang & 0,15 & 0,01 & $-2,43$ & 4,84 & 2,41 \\
\hline 12. Indramayu & 0,00 & 0,00 & 0,00 & 0,00 & 0,00 \\
\hline 13. Subang & 0,43 & 2,04 & $-183,44$ & 232365,82 & 232182,39 \\
\hline 14. Purwakarta & 2,12 & $-0,03$ & 33,89 & $-4943,59$ & $-4909,70$ \\
\hline 15. Karawang & 0,00 & 0,00 & 0,00 & 0,00 & 0,00 \\
\hline 16. Bekasi & 0,00 & 0,00 & 0,00 & 0,00 & 0,00 \\
\hline 17. Bandung Barat $\left.{ }^{*}\right)$ & 1,67 & 7,20 & $-914,17$ & 633065,35 & 632151,18 \\
\hline 18. Pangandaran & 0,00 & 0,00 & 0,00 & 0,00 & 0,00 \\
\hline 19. Kota Bogor & 0,00 & 0,00 & 0,00 & 0,00 & 0,00 \\
\hline 20. Kota Sukabumi & 0,00 & 0,00 & 0,00 & 0,00 & 0,00 \\
\hline 21. Kota Bandung & 0,00 & 0,00 & 0,00 & 0,00 & 0,00 \\
\hline 22. Kota Cirebon & 0,00 & 0,00 & 0,00 & 0,00 & 0,00 \\
\hline 23. Kota Bekasi & 0,00 & 0,00 & 0,00 & 0,00 & 0,00 \\
\hline 24. Kota Depok & 0,00 & 0,00 & 0,00 & 0,00 & 0,00 \\
\hline 25. Kota Cimahi & 0,00 & 0,00 & 0,00 & 0,00 & 0,00 \\
\hline 26. Kota Tasikmalaya & 0,00 & 0,00 & 0,00 & 0,00 & 0,00 \\
\hline 27. Kota Banjar & 0,00 & 0,00 & 0,00 & 0,00 & 0,00 \\
\hline
\end{tabular}

\section{Sumber: Provinsi Jawa Barat Dalam Angka 2014-2016 (diolah)}

Berdasarkan data dan nilai LQ yang diperoleh, wilayah yang memiliki potensi dan menjadi basis sehingga pengambangannya dapat memberikan sumbangsih secara signifikan adalah perkebunan teh di Provinsi Jawa Barat adalah Bandung, Cianjur, Purwakarta, Bandung Barat, Garut, Tasikmalaya, dan Sukabumi.

\section{Laju Pertumbuhan Perkebunan Teh di Jawa Barat}

Hasil data perhitungan komparasi dengan NS menunjukkan bahwa Bandung memiliki laju pertumbuhan perkebunan teh paling tinggi dibandingkan kabupaten/kota lainnya di Provinsi Jawa Barat. Laju pertumbuhan perkebunan teh yang tinggi selanjutnya terjadi di Cianjur, Majalengka, dan Bandung Barat. Hal ini 
menunjukkan adanya potensi dari wilayah tersebut untuk meningkatkan pertumbuhan komoditas teh.

Pada penghitungan PS menunjukkan bahwa pertumbuhan produksi pada komoditas teh yang cepat terjadi di wilayah Bogor, Tasikmalaya, Majalengka, dan Purwakarta yang ditunjukkan dengan nilai PS positif. Penghitungan PS juga menunjukkan bahwa pertumbuhan produksi pada komoditas teh yang lambat terjadi di wilayah Sukabumi, Cianjur, Bandung, Garut, Ciamis, Sumedang, Subang, dan Bandung Barat. Terjadinya hal ini dikarenakan wilayah perkebunan teh yang dimiliki luas, namun tanaman teh yang dikelola saat ini adalah tanaman teh tua.

Pada penghitungan DS menunjukkan bahwa keuntungan komoditas teh yang tertinggi terdapat pada wilayah Bandung, dan selanjutnya adalah Sukabumi, Cianjur, Garut, Bandung Barat dan Subang. Dengan demikian, komoditas teh pada wilayah tersebut memiliki potensi untuk lebih dikembangkan.

\section{Persebaran Kawasan Berdasarkan Potensi Komoditas Teh di Jawa Barat}

Hasil perhitungan dengan kuadran ini menunjukkan bahwa kawasan perkebunan teh yang andalan terdapat pada wilayah Sukabumi, Cianjur, Bandung, Garut, dan Bandung Barat. Wilayah dengan komoditas teh sebagai komoditas unggulan adalah Tasikmalaya dan Purwakarta. Komoditas teh sebagai komoditas prospektif terdapat pada wilayah Bogor, Sukabumi, Kota Bandung, Cirebon, Bekasi, Ciamis, Kuningan, Kota Cirebon, Sumedang, dan Indramayu. Sedangkan, wilayah Bogor dan Majalengka memiliki komoditas teh sebagai komoditas yang tertinggal seperti yang ditunjukkan pada grafik berikut;

\begin{tabular}{|c|c|c|c|}
\hline \multicolumn{3}{|c|}{$\begin{array}{l}\text { Tasikmalaya } \\
\text { Purwakarta }\end{array}$} & $\begin{array}{l}\text { Sukabumi } \\
\text { Cianjur } \\
\text { Bandung } \\
\text { Garut } \\
\text { Bandung Barat }\end{array}$ \\
\hline & Unggulan & 2 & Andalan \\
\hline & Prospektif & 3 & Tertinggal \\
\hline $\begin{array}{l}\text { Kota Bogor } \\
\text { Kota Sukabumi } \\
\text { Kota Bandung } \\
\text { Kota Cirebon } \\
\text { Kota Bekasi } \\
\text { Kota Depok } \\
\text { Kota Cimahi } \\
\text { Kota Tasikmalaya } \\
\text { Kota Banjar }\end{array}$ & $\begin{array}{l}\text { Ciamis } \\
\text { Kuningan } \\
\text { Cirebon } \\
\text { Sumedang } \\
\text { Indramayu } \\
\text { Subang } \\
\text { Karawang } \\
\text { Bekasi } \\
\text { Pangandaran }\end{array}$ & & $\begin{array}{l}\text { Bogor } \\
\text { Majalengka }\end{array}$ \\
\hline
\end{tabular}

Grafik 4. Pembagian Kuadran Berdasar Potensi Komoditas Teh di Provinsi Jawa Barat 


\section{Kesimpulan}

Berdasarkan penelitian, didapatkan wilayah yang memiliki potensi dan menjadi basis sehingga pengambangan dapat memberikan sumbangsih secara signifikan pada perkebunan teh di Provinsi Jawa Barat adalah Bandung, Cianjur, Purwakarta, Bandung Barat, Garut, Tasikmalaya, dan Sukabumi.

Laju pertumbuhan perkebunan teh tertinggi di Provinsi Jawa Barat terjadi di wilayah Bandung. Selanjutnya, untuk wilayah Cianjur, Majalengka, dan Bandung Barat memiliki laju pertumbuhan yang tinggi dibandingkan kabupaten/kota lainnya di Provinsi Jawa Barat. Pertumbuhan produksi pada komoditas teh yang cepat terjadi di wilayah Bogor, Tasikmalaya, Majalengka, Purwakarta.

Hasil perhitungan dengan kuadran ini menunjukkan bahwa kawasan perkebunan teh yang andalan terdapat pada wilayah Sukabumi, Cianjur, Bandung, Garut, dan Bandung Barat. Sedangkan, wilayah Bogor dan Majalengka memiliki komoditas teh sebagai komoditas yang tertinggal.

Berdasarkan hasil penelitian, peneliti dapat memberikan saran bahwa pada wilayah yang memiliki wilayah perkebunan teh dengan sumbangsih yang signifikan dan komoditas andalan namun laju pertumbuhan lambat seperti Kabupaten Bandung, untuk melakukan regenerasi tanaman teh dengan tanaman yang muda. Program ini akan membutuhkan modal besar dan waktu yang cukup lama, sehingga dibutuhkan strategi yang matang dan terencana.

Untuk wilayah yang memiliki prospek baik dan potensi pengambangan lanjutan seperti Sukabumi, Cianjur, Bandung, Garut, Ciamis, Sumedang, Subang, Bandung Barat, sebaiknya dilakukan intensifikasi dan ekstensifikasi lahan perkebunan teh.

\section{Daftar Pustaka}

Badan Pusat Statistik. 2015. Statistik Teh Indonesia 2016. Jakarta: BPS.

Badan Pusat Statistik. 2016. Jawa Barat dalam Angka 2015. Jakarta: BPS.

Badan Pusat Statistik. 2016. Statistik Teh Indonesia 2014. Jakarta: BPS.

Badan Pusat Statistik. 2016. Statistik Teh Indonesia 2015. Jakarta: BPS.

Badan Pusat Statistik. 2016. Statistik Teh Indonesia 2016. Jakarta: BPS.

Badan Pusat Statistik. 2016. Statistik Daerah Cianjur 2015. Jakarta: BPS.

Darmawansyah, Dimas dan Sardjito. 2012. Pengembangan Kawasan Perkebunan Teh di Kabupaten Bandung. Surabaya: ITS.

Edward, Dody. Lahan Perkebunan Terbats, Ekspor Teh Indonesia Terus Menurun. Dikutip 6 September 2019 dari laman https://katadata.co.id/berita/2016/ 11/21/lahan-perkebunan-terbatas-ekspor-teh-indonesia-terus-menurun 
Setianto, Pawit dan Susilowati, Indah. 2014. Komoditas Perkebunan Unggulan yang Berbasis Pada Pengembangan Wilayah Kecamatan di Kabupaten Banjarnegara Provinsi Jawa Tengah. Jurnal Wilayah dan Lingkungan, vol. 2, no. 2, pp. 143-156.

Rakhmawati, Dewi. 2008. Analisis Break Even Point Pada Usaha Pengolahan Pucuk Daun Teh (Kasus Di Pabrik Teh Sumber Daun Kabupaten Cianjur). Surakarta: UNS.

Yusuf, Dede dkk. 2011. Kontribusi Perkebunan Teh Ciater Subang Terhadap Perekonomian Masyarakat Masa Prakemerdekaan. UPI. 